УДК 655.35:655.224.3

() О. Б. Стефанишена, магістрантка, О. В. Зоренко, канд. техн. наук, доц., КПІ ім. Ігоря Сікорського,

Київ, Україна

\title{
СУЧАСНІ ТЕНДЕНЦІЇ РОЗВИТКУ ГЛИБОКОГО ДРУКУ
}

\begin{abstract}
У статті розглянуто сучасні тенденції розвитку глибокого друку на основі аналізу патентних джерел та науково-технічної літератури стосовно технологій виготовлення друкарських форм, друкарського обладнання, витратних матеріалів та сфер застосування у різних географічних регіонах.
\end{abstract}

\section{Ключові слова: глибокий друк; гнучке паковання; друкарська машина; друкарська форма; друкарська фарба.}

\section{Постановка проблеми}

Класичний глибокий метод друку характеризується високими якістю та швидкістю друку, дозволяє великими накладами відтворювати максимально ідентичні відбитки з високими репродукційно-графічними показниками. Попри постійне удосконалення конкурентних офсетного та флексографічного способів друку, глибокий друк все ж зберігає свої позиції на ринку видавничо-поліграфічної продукції також завдяки більш спрощеному процесу підготовки до друку та конструктивним елементам друкарських машин. Ще однією з переваг глибокого друку є висока тиражостійкість друкарських форм, що одночасно визначає найбільший його недолік: високовартісний та довготривалий процес виготовлення друкарських форм, адже саме цей чинник стримує збільшення частки глибокого друку на поліграфічному ринку.

Зважаючи на друкарсько-технічні та репродукційно-графічні властивості глибокого методу, основною сферою його використання є друкування етикеткопакувальної продукції, журналів, рекламних каталогів та шпалер. Нині кількість найменувань журналів та каталогів зменшується з появою смартфонів та інтернету, де реклама стала більш актуальною, причому деякі каталоги стали друкувати офсетним класичним, цифровими способами друку; тому основна продукція глибокого методу $є$ гнучке паковання з полімерних плівок [1-3].

\section{Мета роботи}

Аналіз сучасного стану глибокого методу друку, особливостей 
технології виготовлення друкарських форм та виокремлення причин, що стримують його поширення.

\section{Результати проведених досліджень}

Як зазначалося вище глибокий метод друку активно застосовується для друкування різних видів тари і паковань, зокрема, для гнучкого паковання [4]. Власні дослідження компаній Smithers Pira, PCI Wood Mackenzie, Euromonitor та Mordor Intelligence вказують на приріст ринку гнучкого паковання як за кількістю найменувань, так і в грошових одиницях [5-7], зокрема у звіті компанії Mordor Intelligence (рис. 1) зазначається, що об'єм ринку гнучкого паковання в 2019 році складав \$250,75 млрд, а до 2025 року досягне $\$ 314,98$ млрд із середньорічним ростом у 20202025 рр. у $3,87 \%$ [8].

Згідно Асоціації гнучкого паковання (the Flexible Packaging Association) $60 \%$ - паковання для харчових продуктів. Виробники харчової продукції все більше та частіше роблять тематичні, сезонні оформлення паковання до різноманітних свят та подій, що є однією з багатьох причин зменшення накладів та урізноманітнення замовлень паковання з полімерних плівок. Це визначило основні тенденції виробників друкарського обладнання глибокого методу: удосконалення конструкції друкарських машин (ДМ), створення нових модулів, що сприятиме скороченню часу на переналадку машини між замовленнями, дозволить друкувати малі наклади.

Нині спостерігається збільшення виробництва вузькорулонних ДМ, циліндри для яких більш швидко виготовляються і легше встановлюються в ДМ. Також стали використовувати формні циліндри, в яких матеріалом основи є алюміній чи спеціальна пластмаса, що значно зменшило їх масу, спростило експлуатацію та собівартість порівняно зі сталевими. Наприклад, сучасна ДМ The Dynastar (Windmöler \& Hölschers) містить інтегровані друкарські візки, які легко виїжджають з ДМ і дозволяють готувати машину до наступного накладу, в той час як машина працює [9]. У вузькорулонних машинах Rotocolor Rotova (Rotocolor) формний циліндр, ракель, фарбовий резервуар об'єднані в єдину конструк-
Рис. 1. Об'єм ринку гнучкого паковання за прогнозами компанії Mordor Intelligence

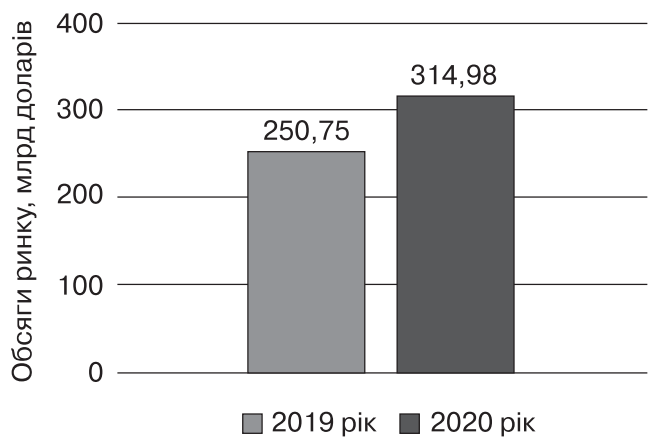


цію, які можна вручну вийняти збоку друкарської секції і перенести ії на транспортувальний візок [10].

У процесі виготовлення друкарських форм (ДФ) досягти значних покращень виявилося важче: суттєві зміни принесло використання технології лазерного гравіювання для запису зображення на ДФ. Ця технологія є більш ефективною і продуктивною за електромеханічне гравіювання, але формне устаткування має високу вартість [11]. Повна автоматизація процесу та сучасних ліній для виготовлення ДФ також дозволили зменшити тривалість технологічних етапів. Але дані розробки не змогли суттєво позбавити глибокий друк недоліків. Хоча останніми роками особливих змін у технології виготовлення ДФ не відбулось, виробники формного устаткування постійно займаються його оптимізацією та удосконаленням. Наприклад, розробка RotoHybrid Cylinders дозволить зменшити вартість і підвищить екологічність виготовлення форм глибокого друку завдяки нанесенню на сталеву основу двох матеріалів: міді, що легко гравіюється та хрому, що забезпечує високу тиражостійкість ДФ. Але хромові ванни, що використовуються в гальванопокритті, є токсичними і екологічно небезпечними для ґрунту, води та повітря, хоча процес нанесення гальванопокриття хрому незаборонений в більшості країн світу, але суворо регулюється. Ця складність не дозволяє більшості поліграфічних підприємств здійснювати власне виробництво ДФ, що значно скоротило б різницю собівартості продукції, надрукованої глибоким та флексографічним методами [12]. Технологія RotoHybrid Cylinders дасть змогу підприємствам виготовляти форми самостійно завдяки тому, що ДФ вкриваються не хромом, а спеціальним алмазоподібним карбоном і містять в собі шар полімеру, що дозволяє виготовляти форми різних діаметрів та довжини та зменшити собівартість виготовлення ДФ на $50 \%$ [13].

Одним з критеріїв вибору способу друку є його собівартість, а згідно з розподілом ринку гнучкого паковання між глибоким та флексографічним методами

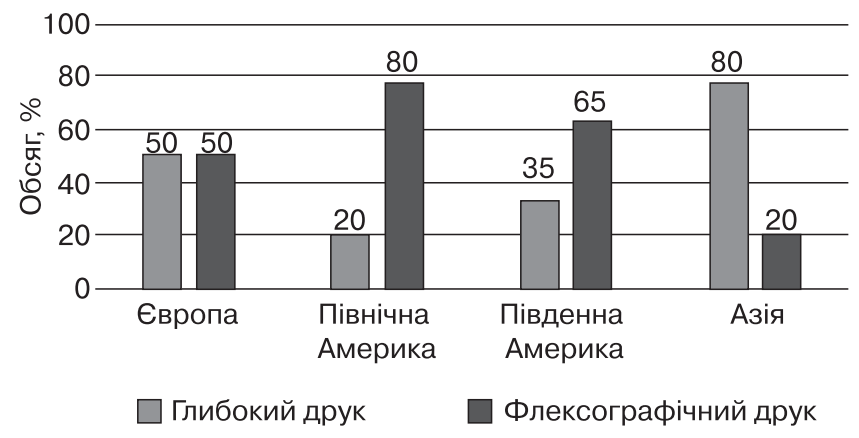

Рис. 2. Розподіл ринку гнучкого паковання між глибоким та флексографічним методами [14] 
(рис. 2), також важливим чинником для замовника є якість друку.

Згідно рис. 2 в Європі глибокий та флексографічний методи ділять ринок гнучкого паковання порівну, при цьому в кожній країні окремо частки флексографічного/глибокого друку різняться (в Італії - 40/60 \%, в Німеччині $60 / 40 \%$, в Польщі - 41/57 \%) $[15,16]$. Глибокий друк досяг високого рівня використання в Азії через можливість якісно відтворювати ієрогліфи, що характерні мовам країн Сходу, а також завдяки великій чисельності даного регіону, що підвищує потребу в пакованні та робить глибокий друк економічно вигідним.

Як видно з рис. 3 в Європі за рік виготовляється 600000 ДФ, в той час як в Південно-Східній Азії (сюди відносяться п'ять країн швидкого економічного розвитку - Тайланд, В'єтнам, Індонезія, Філіппіни, Малайзія) - 830000 ДФ. Якщо до перелічених вище країн додати Китай, Індію та Пакистан кількість ДФ глибокого методу за рік сягатиме майже три млн, що підтверджує ступінь поширення глибокого друку в Азії.
Для визначення тенденцій світового розвитку глибокого методу було проведено патентний пошук з ретроспективою 10 років за 2011-2020 рр. Зокрема, пошук обмежувався такими класами: B41F9, B41C1, C09D11. Як джерела пошуку використано: Europian Patent Office (Esp@cenet), Євразійська патентно-інформаційна система (EAPATIS).

Згідно аналізу наукових джерел основна кількість патентів зосереджена в Азії, 64 \% належить Китаю, який протягом 20112014 рр. конкурував з Японією з майже однаковою кількістю патентів, а з 2015 р. Китай став одноосібним лідером за кількістю патентів. Частина патентів (3 \%) належить США, такі країни Європи як Польща, Німеччина, Італія, Україна також мають опубліковані патенти (рис. 4).

Динаміка патентування за роками не зовсім стабільна, але все ж спостерігається зростання кількості патентів. Зазначимо, що пандемія вірусу COVID-19 вплинула на ситуацію в усіх сферах, включаючи видавничо-поліграфічну галузь. Через збої в роботах підприємств, підвищення попиту

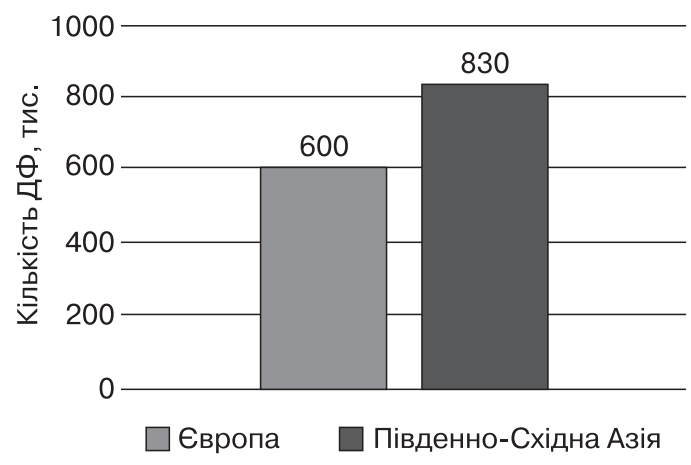

Рис. 3. Кількість виготовлених ДФ глибокого методу за рік [17] 


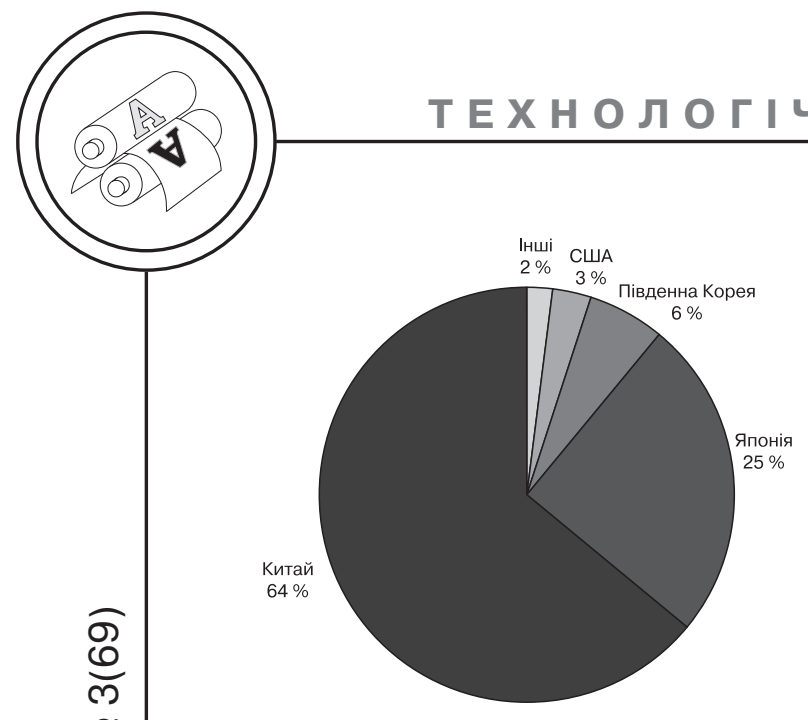

Рис. 4. Діаграма відсоткового співвідношення патентів за країнами

на харчову та гігієнічну продукцію основним приорітетом було відновлення роботи та виконання всіх поліграфічних замовлень.

Основними напрямами патентування (рис. 5) є друкарське устаткування, системи контролю виготовлення друкарських форм, контрольні пристрої руху полотна в ДМ, фарби глибокого друку з різноманітними ефекта-

ми (перламутрові, золоті, срібні, флюорисцентні), фарби для друку на металізованих плівках, УФ-фарби [18-21].

\section{Висновки}

Розглянуто сучасний стан глибокого методу друку, основних тенденцій та напрямів його розвитку згідно досліджень маркетингових компаній та асоціації паковань з плівкових матеріалів.

Проаналізовано сучасні розробки, пов'язані з удосконаленням будови формних циліндрів, оптимізації технологічних процесів виготовлення ДФ та конструктивних елементів друкарського обладнання глибокого методу.

3 позицій співвідношення «собівартість друкованої продукції-якість виготовлення друкованої продукції» порівняно обсяг виробництва паковання з полімерних плівок між глибоким та флексографічним методами друку.

Згідно аналізу науково-технічних та фахових літературних дже-

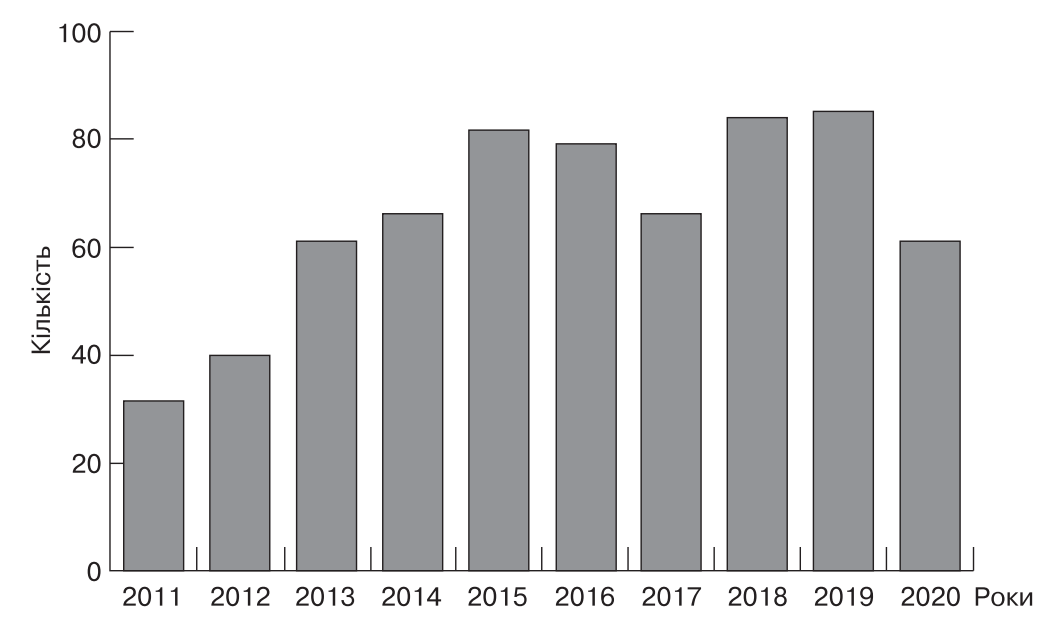

Рис. 5. Динаміка патентування за роками 
рел проведено патентний пошук за країнами та роками за період 2011-2020 рр., визначено основні напрями патентування.

Відповідно до перспективних напрямів розвитку сучасних технологій виготовлення паковань $з$ полімерних плівок подальша робота буде спрямована на дослідження чинників впливу формного та друкарського процесів зокрема, на тиражостійкість ДФ та в цілому на якість виготовлення паковальної продукції глибоким методом друку.

\section{Список використаної літератури}

1. Савченко К. І. Сучасний стан технологій друкування в Україні / К. І. Савченко, О. В. Зоренко, Т. В. Розум, О. М. Величко // Технологія і техніка друкарства. 2011. № 2(32). C. 21-27. DOI: http://doi.org/10.20535/20777264.2(32).2011.52761.

2. Величко О. М. Видавничо-поліграфічна справа. Практикум 3 проектування і розрахунку технологічних і виробничих процесів: навч. посіб. / О. М. Величко. Київ: Видавничо-поліграфічний центр «Київський університет», 2009. 520 с.

3. Величко О. М. Оформлення паковання офсетним друком (технологічні аспекти) / О. М. Величко, К. І. Золотухіна, Т. В. Розум // Упаковка. 2016. № 4. C. 40-43.

4. Н. Дубина. Главные тренды в упаковке: факты и прогнозы / Н. Дубина // КомпьАрт. 2019. № 2. [Електронний ресурс]. Режим доступу: http://compuart.ru/article/25411.

5. The Future of Package Printing to 2025. SMITHERS. [Електронний ресурс]. Режим доступу: http://www.smithers.com/services/market-reports/ printing/the-future-of-package-printing-to-2025.

6. Современные тенденции в гибкой упаковке. MacHouse. 2018. [Електронний ресурс]. Режим доступу: https://machouse.ua/press-center/ s3/publications/covremennye-tendentsii-v-hibkoj-upakovke.html.

7. Развитие украинского рынка упаковки. Мир Упаковки. Июнь, 2019. [Електронний ресурс]. Режим доступу: https://packaging.com.ua/content/4755.

8. Гибкая упаковка: плюсов пока больше, чем минусов, соответственно, и рост неизбежен. 2020. [Електронний ресурс]. Режим доступу: http://printus.com.ua/article/read/4152.

9. New gravure printing press for short runs. Janoschka. 2016. [Електронний ресурс]. Режим доступу: http://www.janoschka.com/de/news/d/newgravure-printing-press-for-short-runs/.

10. А. Самсонов. Глубокая печать для коротких тиражей / А. Самсонов // publish. 5 мая 2008. Електронний ресурс]. Режим доступу: https://publish. ru/articles/5018863.

11. Three decades of gravure form manufacture - enduring and innovative [Електронний ресурс]. Режим доступу до ресурсу: http://www.hell-gravuresystems.com/wp-content/uploads/sites/7/2020/11/30 years Gravure forms.pdf. 
12. Technical Comparison of New Gravure Cylinder Technology. GAA. [Електронний ресурс]. Режим доступу до ресурсу: http://gaa.org/technicalcomparison-of-new-gravure-cylinder-technology/.

13. HYBRID CYLINDERS. [Електронний ресурс]. Режим доступу: https://www.rotohybrid.com/hybrid-cylinders/.

14. Gravure Printing - Status and Trends. 2020. [Електронний ресурс]. Режим доступу: http://meprinter.com/gravure-printing-in-europe-status-and-trends/.

15. Развитие рынка глубокой печати. [Електронний ресурс]. Режим доступу: https://limpack.ru/razvitie-rynka-glubokoy-pechati/.

16. Поліграфія України має всі шанси для розвитку. 2018. [Електронний ресурс]. Режим доступу: http://www.printus.com.ua/article/read/3777.

17. Gravure printing in Europe - status and current trends. [Електронний ресурс]. Режим доступу: http://era-eu.org/rotogravure-industry-news/ gravure-printing-in-europe-status-and-current-trends/509/.

18. Пат. 2020110975 Японія, МПК В05С 1/08; В05C 11/00; В05C 11/10; B41F 33/14; B41F 9/00. Gravure rotary printing device / Ikeda Kazumasa; заявник і патентовласник Toppan Printing CO LTD; заявл. 11.01.2019; опублік. 27.07.2020.

19. Пат. 111073386 Китай, MПК CO9D 11/03; C09D 11/101. LED-UV curing gravure ink and preparation method and application thereof / Hu Hai, Lu Qiting, Gao Xiong, Yu Yalei; заявник і патентовласник Shanghai Kangda Chemical New Mat Group Co Ltd; заявл. 11.12.2019; опублік. 28.04.2020.

20. Пат. 2018053002 Японія, МПК CO9D 11/106. Gravure ink for aluminum substrate and printed matter / Naruhiro Harunori, Yasuda Hideki; Sai Tetsuya; Maeda Daisuke; заявник і патентовласник Toyo Ink Sc Holdings CO LTD; заявл. 26.09.2016; опублік. 05.04.2020.

21. Розум Т. В. Контроль якості друкування на пакованні / Т. В. Розум, Я. В. Зоренко, К. І. Савченко, В. М. Скиба // Упаковка. Журнал для виробників та споживачів тари і упаковки. 2012. № 3. С. 63-66. Режим доступу: http://pvs.uad.Iviv.ua/static/media/1-57/15.pdf.

\section{References}

1. Savchenko, K. I. \& Zorenko, O. V. \& Rozum, T. V. \& Velychko, O. M. (2011). Suchasnyi stan tekhnolohii drukuvannia v Ukraini [The Current State of Printing Technologies in Ukraine]. Journal of Tekhnolohiia i tekhnika drukarstva, 2(32), 21-27. DOI: http://doi.org/10.20535/2077-7264.2(32).2011.52761 [in Ukrainian].

2. Velychko, O. M. (2009). Vydavnycho-polihrafichna sprava. Praktykum z proektuvannia i rozrakhunku tekhnolohichnykh i vyrobnychykh protsesiv [Publishing and Printing Business. Workshop on the Design and Calculation of Technological and Production Processes]. Kyiv: Vydavnycho-polihrafichnyi tsentr 'Kyivskyi universytet', 520 p. [in Ukrainian].

3. Velychko, O. M. \& Zolotukhina, K. I. \& Rozum, T. V. (2016). Oformlennia pakovannia ofsetnym drukom (tekhnolohichni aspekty) [Packaging Design by Offset Printing (Technological Aspects)]. Journal of Upakovka, 4, 40-43 [in Ukrainian].

4. Dubina, N. (2019). Glavnye trendy v upakovke: fakty i prognozy [Top Packaging Trends: Facts and Forecasts]. Journal of Komp'Art, 2. Retrieved from http://compuart.ru/article/25411 [in Russian]. 
5. The Future of Package Printing to 2025. SMITHERS. Retrieved from http://www.smithers.com/services/market-reports/printing/the-future-ofpackage-printing-to-2025 [in English].

6. (2018). Sovremennye tendentsii v gibkoy upakovke [Current Trends in Flexible Packaging]. MacHouse. Retrieved from https://machouse.ua/presscenter/s3/publications/covremennye-tendentsii-v-hibkoj-upakovke.html [in Russian].

7. (2019). Razvitie ukrainskogo rynka upakovki [Development of the Ukrainian Packaging Market]. Mir Upakovki. Retrieved from https://packaging.com.ua/content/4755 [in Russian].

8. (2020). Gibkaya upakovka: plyusov poka bol'she, chem minusov, sootvetstvenno, i rost neizbezhen [Flexible Packaging: So Far there are More Advantages than Disadvantages, Respectively, and Growth is Inevitable]. Retrieved from http://printus.com.ua/article/read/4152 [in Russian].

9. (2016). New gravure printing press for short runs. Janoschka. Retrieved from http://www.janoschka.com/de/news/d/new-gravure-printing-press-forshort-runs/ [in English].

10. Samsonov, A. (2008). Glubokaya pechat' dlya korotkikh tirazhey [Intaglio Printing for Short Runs]. Journal of publish. Retrieved from https://publish.ru/ articles/5018863 [in Russian].

11. Three decades of gravure form manufacture - enduring and innovative. Retrieved from http://www.hell-gravure-systems.com/wp-content/uploads/ sites/7/2020/11/30_years_Gravure_forms.pdf [in English].

12. Technical Comparison of New Gravure Cylinder Technology. GAA. Retrieved from http://gaa.org/technical-comparison-of-new-gravure-cylindertechnology/ [in English].

13. HYBRID CYLINDERS. Retrieved from https://www.rotohybrid.com/ hybrid-cylinders/ [in English].

14. (2020). Gravure Printing - Status and Trends. Retrieved from http://meprinter.com/gravure-printing-in-europe-status-and-trends/ [in English].

15. Razvitie rynka glubokoy pechati [Development of the Gravure Printing Market]. Retrieved from https://limpack.ru/razvitie-rynka-glubokoy-pechati/ [in Russian].

16. (2018). Polihrafiia Ukrainy maie vsi shansy dlia rozvytku [Polygraphy of Ukraine has All the Chances for Development]. Retrieved from http://www. printus.com.ua/article/read/3777 [in Ukrainian].

17. Gravure printing in Europe - status and current trends. Retrieved from http://era-eu.org/rotogravure-industry-news/gravure-printing-in-europe-status-and-current-trends/509/ [in English].

18. Kazumasa, Ikeda. Gravure Rotary Printing Device // Patent № 2020110975 Japan. Publish 27.07.2020 [in English].

19. Hai, H. \& Qiting, L. \& Xiong, G. \& Yalei, Y. LED-UV Curing Gravure Ink and Preparation Method and Application thereof // Patent № 111073386 China. Publish 28.04.2020 [in English].

20. Harunori N. \& Hideki, Y. \& Tetsuya, S. \& Daisuke, M. Gravure Ink for Aluminum Substrate and Printed Matter // Patent № 2018053002 Japan. Publish 05.04.2020 [in English].

21. Rozum, T. V. \& Zorenko, Ya. V. \& Savchenko, K. I. \& Skyba, V. M. (2012). Kontrol yakosti drukuvannia na pakovanni [Quality Control of Printing on the 
Package]. Journal of Upakovka. Zhurnal dlia vyrobnykiv ta spozhyvachiv tary $i$ upakovky, 3, 63-66. Retrieved from http://pvs.uad.Iviv.ua/static/media/157/15.pdf [in Ukrainian].

The article considers the current trends in the development of gravure printing based on the analysis of patent sources and scientific and technical literature on the technology of printing plates, printing equipment, consumables and applications in different geographical regions.

\title{
Keywords: gravure printing; flexible packaging;
} printing machine; printing form; printing ink.

\author{
Рецензент - Т. В. Розум, канд. техн. наук, \\ доц., КПІ ім. Ігоря Сікорського
}

Надійшла до редакції 12.10.20 